\title{
The Importance of Integration Waste Management Aspects as a System in Good and Sustainable Waste Management
}

\author{
Abdul Mukhit ${ }^{1 *}$, and Syafrudin Syafrudin ${ }^{2}$ \\ ${ }^{1}$ Master Program in Environmental Sciences, Graduate School of Diponegoro University, Semarang - Indonesia \\ ${ }^{2}$ Department of Environmental Engineering, Faculty of Engineering, Diponegoro University, Semarang - Indonesia
}

\begin{abstract}
Waste management is one of the important issues in environmental management. The city becomes a place of human activity that has the potential to generate waste. Unsustainable waste management has the potential to cause various environmental problems. Waste management starts from the upstream to downstream levels so that it can reduce the amount of waste generation. The importance of integtation in a waste management system is a must and requires seriousness in applying it for create a good and sustainable Waste Management system.
\end{abstract}

Keywords: Municipal Waste, Waste Management, Sustainable, Integtation

\section{Introduction}

Trash is one of the crucial issues in the urban environment problems. Human activities are increasingly complex and dynamic. In its efforts to carry out such complex and dynamic activities, humans need various supporting infrastructure to be able to carry out community activities safely, orderly, healthy and smoothly. Of the various human activities will surely produce residual . According to Law No. 8 of 2008, waste is the remains of human daily activities and / or solid natural processes. For some people garbage is something that has no economic value so it is discarded, however, there are parties who consider that waste as something of economic value and have benefits .

The volume of waste is very related to the development of the population, changes in the quality and dynamics of the activities of a city community. The source, shape , type and composition are strongly influenced by the level of community culture and its natural conditions, the more advanced the level of community culture, the more complex the sources and types of waste are encountered. Rapid urban population development is inseparable from the influence of various technological advances, transportation and so on. This is because the city is the most likely location in supporting the productive activities of a society. Population growth, changes in consumption patterns, and people's lifestyles have increased the amount of waste generation, types and diversity of waste characteristics. The increase in people's purchasing power towards various types of staples and technology products as well as the increasing business or activities supporting the economic growth of a region also contribute greatly to the quantity and quality of waste produced. In line with the increasing volume of solid waste generation waste management that does not use methods and techniques of waste management that are environmentally friendly, other than can cause negative impacts towards health will also greatly disturb the sustainability of environmental functions.

The decreasing quality of the environment needs to be improved in order to ensure the welfare and quality of life in the future. Humans have behaviors that are able to influence lives and welfare of humans and other living things.

Waste management can mean growing and inspiring participation [1] awareness and people's behavior in reducing waste and garbage production. Waste management is also a form of preventive action against various environmental problems such as greenhouse gas emissions $\left(\mathrm{CH}_{4}\right)$ [2], water pollution due to landfill [3] and soil pollution. Waste composition is generally dominated by organic waste. Organic waste is biodegradable and has the potential to produce greenhouse gases. Appropriate waste management is expected to reduce the amount of greenhouse gases released into the air and can be one of the supporting factors and methods in realizing a community that is aware of health and environmental sustainability through the development of low carbon communities. Waste management can be started from the source of waste by sorting waste, followed by the collection process to the final disposal site (TPA). The potential range of waste that is reused and recycled depends on waste generation, waste composition and waste characteristics.

One challenge and the problem faced by the manager in handling waste is due to an imbalance between waste

Corresponding author: doel.mukh@gmail.com 
production and ability to manage it. In the waste management system, there are 5 aspects that are interrelated and mutually supportive in achieving good waste management goals (SNI 19-2454-2002).

Under these conditions, necessary to study which aims to emphasize the importance of five waste management aspects.

\section{Municipal Waste}

The city has become a gathering place for many activities and human activities in various fields. From these various activities, it must produce residual and waste. So it is not surprising, with the many activities carried out by humans, the city becomes a potential waste producer. Waste can be defined as the residual from various of humans and animals activities in the form of solid, mud, liquid or gas which is no longer useful or no longer needed [4]. According to Law No. 18 of 2008 on Waste Management, states that waste is not a regional problem but is a national problem and requires integrated and comprehensive handling so that it can provide benefits to the community in terms of economy, health, behavior and provide positive benefits for the environment.

According to Indonesian National Standard 193983-1995, waste originates from (1) Housing, which consists of permanent houses, semi-permanent houses and non-permanent houses. (2) Non-housing, consisting of: offices, shops, markets, schools, places of worship, roads, hotels, restaurants, hospital industries and other public facilities. Further explained the average amount of waste generation from waste sources that have been explained at the beginning, presented in the table below:

Table 1. The Amount of Waste Generation Based on Waste Source

\begin{tabular}{|c|c|c|c|c|}
\hline No. & $\begin{array}{l}\text { Waste } \\
\text { Source }\end{array}$ & Unit & Volume & Weight $(\mathrm{kg})$ \\
\hline 1. & $\begin{array}{l}\text { Permanent } \\
\text { House }\end{array}$ & $\begin{array}{l}\text { Person } \\
\text { per day }\end{array}$ & $2.25-2.50$ & $0.350-0.400$ \\
\hline 2. & $\begin{array}{l}\text { Semi } \\
\text { Pemanent } \\
\text { House }\end{array}$ & $\begin{array}{l}\text { Person } \\
\text { per day }\end{array}$ & $2.00-2.25$ & $0.300-0.350$ \\
\hline 3. & $\begin{array}{l}\text { Non } \\
\text { Permanent } \\
\text { House }\end{array}$ & $\begin{array}{l}\text { Person } \\
\text { per day }\end{array}$ & $1.75-2.00$ & $0.250-0.300$ \\
\hline 4. & Office & $\begin{array}{l}\text { Employee } \\
\text { per day }\end{array}$ & $0.50-0.75$ & $0.025-0.100$ \\
\hline 5. & Store & $\begin{array}{l}\text { Officer } \\
\text { per day }\end{array}$ & $2.50-3.00$ & $0.150-0.350$ \\
\hline 6. & School & $\begin{array}{l}\text { Student } \\
\text { per day }\end{array}$ & $0.10-0.15$ & $0.010-0.020$ \\
\hline 7. & $\begin{array}{l}\text { Secondary } \\
\text { arterial road }\end{array}$ & $\begin{array}{l}\text { Meter per } \\
\text { day }\end{array}$ & $0.10-0.15$ & $0.020-0.100$ \\
\hline 8. & $\begin{array}{l}\text { Secondary } \\
\text { Collector } \\
\text { Road }\end{array}$ & $\begin{array}{l}\text { Meter per } \\
\text { day }\end{array}$ & $0.10-0.15$ & $0.010-0.050$ \\
\hline 9. & Local Road & $\begin{array}{l}\text { Meter per } \\
\text { day }\end{array}$ & $0.05-0.10$ & $0.005-0.025$ \\
\hline 10. & Market & $\begin{array}{l}\text { Meter per } \\
\text { day }\end{array}$ & $0.20-0.60$ & $0.1-0.3$ \\
\hline
\end{tabular}

\section{Problems and Alternative Solutions in Waste Management}

Waste management in Indonesia is formally stipulated in Indonesian National Standard 19-24542002 which states that the waste management system is a unity of waste management that support each other, and interact in order to achieve the goal of obtaining clean, beautiful, healthy and orderly city. The relationship between these aspects of management as in the picture below:

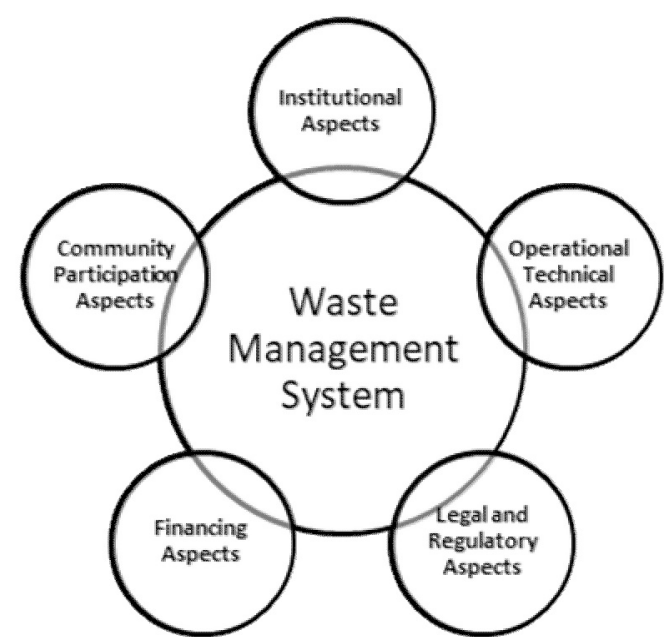

Figure 1. Relationship between Waste Management Aspects in the Waste Management System

\section{A. Institutional Aspects}

Based on Article 26 and Article 27 of Law No. 18 of 2008 , the government as a waste administrator can collaborate in waste management with the private sector or waste management in the form of partnerships. One example is the partnership between the Batam City government and the private sector in the form of concessions [5], where waste management will be handed over entirely to the private sector and the government will get payment from the profits.

The government is the driving force mandated by authorities in carrying out all aspects of management to produce solid and sustainable waste management services with an environmental perspective. Various strategic steps such as increasing the intensity of socialization, education, consultation, mentoring and pioneering [6] expected to be able to motivate the community better in handling waste. Alternative strategies that can be implemented as an effort to overcome waste problems, among others [7] :

- Certainty, status and capacity of the management institution;

- Improving the performance of management institutions;

- Increased cooperation and coordination with the parties ; 
- Improving the quality of human resources for waste management.

\section{B. Operational Technical Aspects}

The operational technique in the waste management system depends on the amount of waste that will be transported to landfills. The condition and limitations of infrastructure and limited land area as a place for processing and disposal of final waste become a common problem in various regions in Indonesia. This operational technique consists of :

1. Storage is the initial stage in waste management operations. The storage is done to facilitate the collection process. At this stage it can be done waste sorting process. Waste sorting process could be the determining point of the effectiveness to next waste management system, while in many cities in Indonesia waste sorting process is carried out at temporary dump or final disposal [8]. Sorting organic waste can be used as compost which is very good for plants [9] whereas plastic waste can be reused or recycled [10].

2. Collection, is a series of moving waste from storage to temporary dump. In general, the tools used to collect are in the form of carts or garbage rickshaws.

3. Displacement, is the following step from the garbage operational techniques where the waste in the temporary dump is then transferred to the truck to be taken to the landfill or final disposal.

4. Transportation, is an important stage in waste operational techniques. The effectiveness and efficiency of transportation can be a benchmark for successful waste management. Delaying the waste transportation causing increase the next waste loading and risk of disrupting the environmental comfort. Planning, evaluation and monitoring of facilities, routes and transportation schedules are important.

5. Final disposal / processing, is the end of waste operational techniques which is then the waste treated with proper management and utilization. One of the waste management efforts that can be done is by adding efective microorganisms (EM4) which affect the quality of compost maturity which is better than the natural composting process for in accordance with quality standards of mature compost [11]. Principly, the final disposal is to destroy waste as an effort to minimize environmental problems. In Indonesia, waste processing methods include: open dumping , Contoll Landfill, Sanitary Landfill, composting , and burning.

In order to overcome the problem of this aspect, it is necessary to increase the effectiveness and increasing of waste operational services. Several strategies that can be done [7], among others :
- Optimizing the utilization of infrastructure and facilities,

- Improve service coverage in a planned and fair manner,

- Increase the capacity of garbage facilities according to service target,

- Landfill rehabilitation from pollution,

- Improve the quality of landfill management towards sanitary landfill,

- Research, development and application of appropriate and environmentally-friendly solid waste.

\section{Legal and Regulatory Aspects}

The management regulation policy in the regions has not been able to provide motivation and awareness of community participation in getting involved directly or indirectly in management both in terms of financing and in terms of operasonal techniques.

Waste problem is not a regional problem, but it is a national problem. This is evidenced by the Law on waste management nationally regulate all waste issue and be a reference for the regional goverments.

Seen from law viewpoint in the rules and regulations, there are two aspects that can be set up and become the basis for waste management provision is the management and technical aspects. From the aspect of management in general and universal waste management legislation, it regulates fundamental positions, rights and responsibilities (community, government and business world), while from technical point of view technical provision (technology, funding, supervision, and participation) community) and administrative and criminal sanctions [12].

\section{Financing Aspects}

The problem that often faced in the aspect of financing is the unbalanced amount of operational and maintenance with the amount of retribution cost. Waste management is not running optimally because of this.

The government and the community are the parties that need each other and determine each other in an effort to solve the problem of waste financing. One of the forms of community participation in waste financing is to pay waste retribution which is expected to reach a better level [12].

\section{E. Community Participation Aspects}

Community participation in waste management is the involvement as individuals or communally both directly and indirectly [13]. One example of direct participation is the application of the $3 \mathrm{R}$ principle [14] which is the main principle of waste management through the waste bank [15]. Waste banks optimation and revitalize is an initiate step tp handling the waste the source [16] . The bottom-up of community participation 
is the result of social and cultural character in managing waste.

Waste management with community participation is able to reduce waste management, efficiency of management costs compared to conventional management and increase economic value and create social harmony in society [17]. Another form of community participation is the empowerment of the community itself. Community empowerment is considered to be able to increase knowledge and attitudes in waste management significantly [18].

Jorge in Syafrudin [19] stated that one of the obstacles in community participation is the ability to pay differently in society and community life patterns. Community participation will be smaller if financial conditions are relatively limited.

Community partisipation in waste management system includes a system of oversight, management, utilization, and funding. In the supervision system there should be a clear and transparent mechanism in which the community becomes a control function in waste management. The community can actually act as human resources who conduct operations and maintain the waste transportation, the anaerobic / biogas processors [20] and incinerator. The use of waste by the community can be done by composting waste and utilizing other economic activities such as handicrafts, recycling and other production raw materials. Besides the community, the private sector / business world also has great potential to be able to participate in providing this public service. Some bad experiences in the past often burdened the business world so that they did not develop and needed improvement efforts. The private sector should no longer be used for other purposes, but needs to be seen as a partner to jointly realize services to the community so that their presence is indispensable.

\section{Conclusion}

From the description above, it can be drawn some conclusions are :

a. In the urban waste management system in Indonesia, there are five aspects, namely, institutional aspects, operational technical aspects, legal and regulatory aspects, financing aspects and community participation aspects, which with respect to each other so that it requires a coordinated network with one another.

b. Waste management in Indonesia is one of the crucial problems, the social problems tend to be more influential than the technological problems, because it involves the problem of customs and culture of Indonesian society.

c. Various alternative solutions for waste disposal should be reviewed as a integrated system that waste management systems in Indonesia will lead to integrated and sustainable urban waste management involving these five aspects.

\section{References}

[1] Lailiy Muthmainnah, "Revitalizing Participation \& Building Synergy :," Journal Social Sciences and Political Science,11 no. November, pp. 267-286, (2007).

[2] Wawargita Permata Wijayanti, "Waste Management Opportunities As a Mitigation Strategy in Realizing Semarang's Climate Resilience," Journal of City Development Area, 9, no. 2, pp. 152-162 (2013)

[3] Lilis Prihastini, "IMPACT OF THE WINONGO WASTE OF END (TPA) ON THE ENVIRONMENTAL QUALITY," Journal Researcher Health Sound Forikes , 2, no. 1, pp. 715 (2011)

[4] Tchoba6noglous, G., Teisen H., Eliasen, R, 1993, Integrated Solid WastenManajemen, Mc.Graw Hill : Kogakusha, Ltd

[5] Irawan Wisnu Wardhana and Nasrullah, "Study of the Potential of Public and Private Partnership in Waste Management in Batam City," Journal PRECIPITATION , 5, no. 2, pp. 90-98 (2008)

[6] Ambar Teguh Sulistiyani and Yulia Wulandari, "Sitimulyo Village Community Empowerment Process, Piyungan District, Bantul Regency in the Formation of Independent Waste Management Group," Indonesia. Journal of Community Engagem, 2, no. 2, pp. 146-162, (2017)

[7] Anonymous. 2006. Minister of Public Works Regulation Number: 21 / PRT / M / 2006 concerning National Policy and Strategy for Solid Waste Management System Development. Minister of Public Works: Jakarta.

[8] Alin Sri Maulina, "Identification of Community Participation in Waste Sorting in the District of North Cimahi and the Affecting Factors, "Journal of Urban Development and Planning, 23, no. 3, pp. 177-196 (2012)

[9] Siti Amanah, Intan P. N. Damanik, and Helda Ibrahim, "UTILIZATION OF WASTE TO SUPPORT DRUG PLANT BUSINESS (Waste Utilization to Support Herbal Medicine Family Enterprise and Agroecosystem in Benteng Village, Ciampea, Bogor District) Faculty of Agriculture, J1 Perintis Kemerdekaan Km 9/29 , Makassar 9024, Journal of Human and environment, 21, no. 1, pp. 90-97, (2014)

[10] Ririn Setyowati and Surahma Asti Mulasari, "Knowledge and Behavior of Housewives in Plastic Waste Management," Journal of National Community Service. Public Health, 7, no. 12, p. 562 (2013)

[11] Mochamad Arief Budihardjo, "Study of the Potential of City Waste Composting As One Alternative for Managing Waste in Landfill by Using EM4 Activator (Effective Microorganism)," Journal Precipitation, 1, no. 1, pp. 25-31, (2003) 
[12] Dyayadi. Urban Planning According to Islam. Khalifa. Jakarta (2008)

[13] Viradin Yogiesti, Setiana Hariyani and Fauzul Rizal Sutikno, "Integrated Community-Based Waste Management in Kediri City," Journal of Urban and Regional Palnning, 2, no. 0341, pp. 95102 (2010)

[14] Yuni Puspitawati and Mardwi Rahdriawan, "Study of Community-Based Waste Management with the 3R Concept (Reduce, Reuse, Recycle) in the Larangan City of Cirebon Village," Journal of Urban and Regional Development, 8, no. 4, pp. 349-359, (2012)

[15] Hadhan Bachtiar, Imam Hanafi, and Mochamad Rozikin, "Development of Waste Banks as a Form of Community Participation in Waste Management (Study on Malang Waste Bank Cooperative), "Journal of Public AdministrationI", 3, no. 1, pp. 128-133 (2015)

[16] Budi Prasetyo Samadikun, Dwi Siwi Handayani, and Muhamad Permana Laksana, "Revitalizing the Management of Waste Banks in Palabuhanratu,
"Journal PRECIPITATION", 14, no. 2, pp. 68-74 (2017)

[17] Beta Dwi Utami, Nastiti Siswi Indrasti, and Arya Hadi Dharmawan, "Community-Based Household Waste Management: Exemplary from Two Communities in Sleman and South Jakarta ," Journal of Social Transdisciplinary Sodality. , 2, no. 01, pp. 49-68, (2008)

[18] Tati Ruhmawati, M. Karmini, and Dwi Tjahjani P., "Increasing Knowledge and Attitudes of the Family Head on Waste Management through Family Empowerment in Tamansari Village, Bandung City," Journal of Health. Circle Indonesia. , 16, no. 1, p. 1, (2017)

[19] Syafrudin, CES, Ir. MT, 2004, Community Based Waste Management Model (Preliminary Study For Case of Semarang City), Paper on Interactive Discussion: Integrated Urban Waste Management, Master Program of Environmental Science UNDIP.

[20] Alberto Dirhantarpo, "Biogas from municipal waste. Pdf," Agritech , 2, no. 2, pp. 25-27, (1981) 